\title{
The Economics of Happiness: Tourism Development, Neocolonialism and Marginalization in Local Traditional Communities
}

\author{
Intan Purwandani \\ MSc Candidate of Leisure, Tourism, and Environment \\ Wageningen University Research, The Netherlands \\ Email: intan.purwandani@wur.nl
}

\begin{abstract}
This scientific article takes as a starting point a series of studies done by anthropologist Helena Norberg-Hodge which resulted in the documentary "The Economics of Happiness" which explains the interrelation between globalization, economics, and happiness among a society. Through a study case in the Indian community of Ladakh, Norberg-Hodge witnesses with her own eyes the negative repercussions of globalization as a force which disintegrated the self-subsistence structure and undermined alternative ways of development other than the Westernized profit oriented understanding of the concept. The main objective of the present article is therefore to analyze the globalization phenomenon as a neocolonial movement and how this has resulted in economic and social forms marginalization for traditional rural communities where tourism development has arisen. By analyzing two case studies in former colonized areas that are now touristic destinations, we find empirical evidence supporting our main argument. It has been found that globalization is indeed a movement lead by apparent neoliberal principles which promote global integration and promise economic development to Third World Nations, but in reality, it results in an asymmetrical situation in which Western developed countries reap more benefit out of it than developing nations. Furthermore, local communities are economically and socially marginalized within their own localities.
\end{abstract}

Keywords: tourism, globalization, neocolonialism, marginalization

\section{Introduction}

Globalization is generally seen as the process of deregularization of barriers in favor of free mobility and free trade to enhance global economic development within nations (Garioua, 2014; Mukhreij, 2014). Revolving around the discourse of bringing economic development to underdeveloped countries, at a simple glance it seems to be positive movement for traditional communities which live under "poor" conditions (Norberg-Hodge, 2011). However, when examined more closely, this discourse is strongly driven by western values, which are merely focused on profit and economic development and by nature undermine other forms of development and livelihoods, considered by western standards to be primitive (Norberg-Hodge, 2011).

According to Norberg-Hodge (2011) globalization is defined in the following two ways: (a) the deregulation of trade and finance in order to enable businesses and banks to operate globally; (b) the emergence of a single world market dominated by transnational companies. The author states that this movement originated from the colonial times, whereby the dominant empires of the world imposed their will over the people and resources of the colonized areas. Prior to globalization and after the apparent independence of the colonies, 
the power over them still remained through foreign debt. Currently, globalization masks the remaining of colonial ties, being in reality a movement led by governments and lobbied by powerful multinational western corporations seeking profit, through the apparent discourse of economic development as being a synonym of wellbeing (Norberg-Hodge, 2011; Goldsmith, 1997; Escobar, 1994).

As part of this movement in the tourism field it has becomes evident how the economic factors are prioritized over other facets of the human life such as socio-cultural and ecological facet and spiritual facet representing the core for their traditional livelihoods and hence form of survival (Bodley, 2008; Norberg-Hodge, 2011). Taken from a case study in the remote area of Ladhak in India, Norberg-Hodge (2011) outlines the negative repercussions of tourism in this area after the construction of a road subsidized by the government and powerful corporations. The aperture to tourism brought with it prior inexistent issues such as junk food, plastic consumer goods, pollution, and the introduction of toxic chemicals such as DDT and asbestos. Other impacts within the rural traditional community which once was healthy and selfsustained are described by Norberg-Hodge (2011) as follows: "Western-style education, television and advertising - glamorizing an urban consumer lifestyle - have had a dramatic psychological effect, giving the impression that life in the West is one of limitless wealth and leisure and, in turn, that rural life and traditional culture are primitive and inferior".

More importantly, through the flow of tourists, Norberg-Hodge (2011) states that the spread of western values within the hosting nonWestern countries has led to the loss of cultural identity. Rural and traditional communities question their own principles regarding development and see their own selves as inferior and underdeveloped compared to their Western counterparts. The use of resources has also shifted towards satisfying the needs of this new tourism service consumers and are being placed above the needs of the community itself because of the economic incentives imposed by globalization (Norberg-Hodge, 2011). This has led to the marginalization of the rural traditional communities within their own territories (NorbergHodge 2011).
The question that arises as purpose of this study is: how does tourism development in the globalized era, driven by a westernized neo-colonial discourse, leads rural traditional communities to the marginalization within their localities?

The main aim of this article, therefore is to discover how the current globalization discourse (focused mainly in economic development) which drives tourism development, has undermined other forms of development within rural traditional communities in what are considered to be underdeveloped countries by western standards.

\section{Theoretical basis}

In today's world, the discussion regarding globalization and development can be seen from many perspectives. From the hyperglobalist point of view globalization can be seen as a period characterized by the "denationalization" of economy and global integration in favor economic growth. Specifically, according to Levy (2012) this is reflected on the development of standard of living, commodification of goods and services resulting in competition and increased access to technology. According to this perspective, economic development which has been brought by globalization is driven by neoliberalist principles primarily based on the idea of competition. Neoliberalism sees competition as the process of rewarding merit and punishing inefficiency resulting from the democratic choices of citizens (Monbiot, 2016). It has been argued that the successful integration and interconnectedness between nations and states in the globalized era is dependent on the current socioeconomic and political conditions of each locality (Cheng \& Mittelhammer, 2017). In other words, it is dependent on their performance and capacity of their social capital and institutions. These two aforementioned aspects argued as the obligatory foundation necessary for local civic engagement and institutions to accommodate and confront the idea of economic development brought by First World countries through globalization.

The idea of development previously highlighted is mainly economic growth-centered, which for some critics, as explained later, is lacking an integral holistic picture of the phenomena of globalization. However other scholars have 
constructed further into this perspective evolving into a people-centered development. Pongsapich (2003) states that transnational companies within the globalization process offer a way to employ and empower local human resources resulting in civil society taking an active a role within the development process. The author continuously explains that partnership between locals and transnational group offer many opportunities to create broader network and global inclusiveness. In the field of tourism, the idea of creating integration and global inclusiveness between global and local engagement can be reflected in the concept of glocalization. This concept explains how the combination of global and local forces result in a positive, unique outcome (Ritzer, 2003). To sum up, the idea of global and local integration counter traditional arguments that mainly said globalization through economic development affects marginalization among locals.

However, there are theories that criticize the previous standpoint regarding the beneficial effects of globalization for the integration of localities into a global community. According to several authors the origins of globalization is the result of a colonial discourse. Goldsmith (1997) in his essay entitled "Development as Colonialism", argues that the main aim to industrialize underdeveloped countries after World War II was not merely for philanthropic reasons and social integration. Rather it was motivated by the need to incorporate the Third World into the Western trading system with the purpose of creating a global market for the Western goods and services and at the same time obtaining a source of cheap labor and raw materials for this global industry to work in their favor. Escobar (1994) indeed agrees with this stream of thought, arguing that development has arisen with a strong colonial discourse behind it. He states that nonEuropean areas have been systematically organized into and transformed according to the European constructs which, originated in the early post World War II period, offered development as a tool for poverty alleviation to underdeveloped countries.

Regarding this theory about globalization as a modern form of colonization, Korten (1998) discusses how this phenomenon works as the means through which corporations from Western developed countries gain more power, market and access to resources in a global scale. The author states that the aims of exploitation that originated in the colonial period are still alive, except that now in modern times they are masked by a set of neoliberal principles which promise economic development to the "underdeveloped". McLaren (2003) claims that within the tourism industry, because of being part of the globalization phenomenon, such corporate imperialism strongly dominates. The author emphasizes on the role of foreign government and aid in the contribution of building the infrastructure in which the tourism industry depends on to thrive in underdeveloped countries. Such initiatives according to Norberg-Hodge (2011) are also primarily lobbied by big profit-driven corporations with origins in developed countries.

In addition to this the author states that in the globalization discourse the focus is in economic development, discarding other forms of development such as ecological, spiritual and sociocultural which result in the marginalization of the host community within their own territory. Bodley (2008) supporting this argument, explains how in the modern economic system, economic power is concentrated in giant corporations which are organizationally far removed from the domestic concerns and needs of local individuals and households. Thus, the author states that the commercial world and the commercialization process undermine what he calls the "humanization process". This, he explains, consist in the necessary stages for small scale traditional communities to reach the sociocultural structure and natural resource management within their livelihoods in order to be self-sustained. He refers upon the cases of autonomous tribal groups to exemplify this type of marginalization which, because of the globalization effects of expansion, have been driven to ecocide. This means that the natural resources for which they depend on are used as commercial commodities in the global market. Because of the pressure globalization exerts on small scale traditional rural communities towards becoming profit oriented, it is suggested that other facets of their development are under attended resulting in the disintegration of what was once the core of their survival.

As referred to before, Norberg-Hodge (2011) has also explored the negative impacts of globalization and how marginalization has taken 
place in a once remote and self-sustained rural community known as Ladakh in India. The case study portrays the impacts of the construction of a road subsidized by the government and lobbied by multinationals over the community. The rural traditional community was transformed because of the exposure to new pressures prior non-existent to them. The author argues that where once there was a small scale strongly bonded community relying solely in basic self-subsistence, now they are exposed to new economic issues such as poverty, unemployment, social stratification and environmental issues previous inexistent such as pollution and exposure to chemical toxins. New sociocultural issues have also arisen, because of the influence of the media and western consumerist culture, the members of the community started questioning their own cultural identity and considering themselves to be inferior and primitive in relation to their developed western counterparts. The forces of tourism within the area exemplify this marginalization, since the influx of tourists coming with western standards of consumption demand products and services that exert pressure over the natural resources originally used for the subsistence of the local people.

Because neoliberal and profit-driven pressures, the once self-sustained community of Ladakh prioritized the needs of those activities which promise economic development over those that were once the core of their everyday living and source of survival. The main argument explored in this article revolves around how the forces of the phenomenon of globalization, driven by a neocolonial western forces and corporate domination, brings new unknown economic pressures into small scale traditional rural areas. I will argue that this results in the undermining of ecological, spiritual and sociocultural development of this communities and the marginalization within their own territory. For this purpose, within the following framework, I will focus in the concept of globalization as a form of neo-imperialism and its relation to different forms of marginalization.

\subsection{Globalization as a form of Neocolonial}

Globalization originally arose out of international economic activities and reforms, however implicitly this means penetrating also into political, socio- cultural and ecological domains (Zao and Li, 2005). According to the authors, taking an approach based on political economy, it is seemingly a process of inclusive transformation to globally integrate all countries into economic development. However, in reality due to historical and socio-political reasons, developing countries are placed in an extremely disadvantaged position. Lead by modern neoliberal principles, globalization nowadays is characterized because of the implementation of voluntarist politics, strongly influenced by wealthy developed countries and tailored up for their own development needs (Amin 2000). This, the author argues, is driven by the unilateral logic of capitalist expansion.

Although neoliberal initiatives are claimed to promote pro-development inclusive ideals such as a free market, the encouragement of private enterprise and consumer choice, behind this discourse lies the power and influence of corporations that engage in public relation efforts to give these terms a near sacred aura (McChesney, 1998). The author establishes that through the persuasive efforts from corporations these claims are accepted almost by default by society without being questioned, and are used to rationalize and justify any movement in favor of their own profit, such as globalization. Any activity that might intervene with corporate domination of society is automatically suspected as interfering with the principles of a free market which is alleged to be the only rational, fair and democratic allocator of goods and services (McChesney, 1999).

Having understood the origins of globalization from a political economy approach as a neoliberal movement, Patnaik (2000) constructs over this to explain how the internationalization of social, political and economic life has arisen from a neocolonialism perspective, placing Third World countries in an inferior position in relation to the First World country counterpart. Two interrelated, destructive effects derived from globalization can be identified as follows: (1) being a process of relative unity among the advanced capitalist countries as opposed to an inter-imperialist rivalry; and (2) being a process of common purpose against developing countries on the part of the united capitalist powers (Patnaik, 2000). As a result, Third World nationalism is denied, opportunities for economic 
self-reliance taken away and the acceptance of a global order dominated by the power of advanced capitalist countries is imposed ( $\mathrm{Zao}$ and $\mathrm{Li}, 2005$ ).

Therefore, the authors argue that by examining the phenomenon of globalization from the perspective of political economy, rather than understanding it as a pro-development movement it is more likely to be labelled as a modern form of "imperialism" or "neo-imperialism". It can be said therefore that globalization is a form of prevalent neocolonialism.

\subsection{Marginalization}

Hall (2013) defines marginalization as a condition of disadvantage that may arise from unfavorable environmental, cultural, social, economic and political factors. Third World nations are being marginalized through the process of globalization in many senses of the word. As referred to in the previous section globalization is claimed to promote the accelerated integration of the world economy in a global scale and not just at a regional level (Murshed, 2002). However, and as explained by the neocolonial perspective, an underlying process could be in operation since globalization appears to do the exact opposite of what it preaches. It actually reinforces the polarization between the rich and the poor, and as described by Quah (1996) it cements the "persistence and stratification" of the differences between these two socioeconomic extremes. As time goes by a bi-modal distribution of world income emerges consisting on one side of affluent nations and on the other of low-income countries, and nations around the world are forced into joining one group or the other (Murshed, 2002).

Regarding the relationship of marginality and neocolonialism Spivak (1999) introduced the term of post-coloniality referring specifically to the imperialistic and capitalistic strategies used by the West to marginalize the third world population. An evident income disparity between developed and underdeveloped countries has arisen since the globalized era started as discovered by Milanovic (2002). Murshed (2002) emphasizes that within this era "nations in the developing world remain vulnerable to domestic and external shocks and seem unable to cash in the on the increased internationalization of the world economy" (p. 2). Therefore, he states that Third World nations are being marginalized from the world economy.

Through this process these countries are not only deprived from tangible economic benefits but also from social structures that where once their alternative to survive. Their traditional livelihoods are also being undermined (State, 2010) meaning with this their ways of survival, including capabilities, claims and access to resources (Bebbington, 1999; Chambers and Conway, 1992; Leach et al., 1999). As defined by Leonard (1984) social marginalization can be understood as "being outside the mainstream of productive activity and/or social reproductive activity" (p.180). As globalization progresses and capitalism extends its reach, communities are dispossessed of lands, livelihoods, or systems of social support (Chomsky, 2000; Petras \& Veltmeyer, 2001; Potter, 2000; Pilger, 2002).

\section{Research Methodology}

As a method, this study focuses on the case study in two different developing countries namely (1) the coastal tourism development case in Petite Cote, Senegal and (2) the indigenous village of Antanosy in Evatra, Madagascar. By using secondary data analysis on already existent literature, this research analyzes and discusses how the development of tourism industry driven by Western values result in the marginalization of local communities. To provide a logical order, this paper is outlined as follows:

1. The first section revolves around literature review, where it will be explained the discussion debate among scholars in relation to the positive and negative impact of globalization regarding economic development.

2. The second section consists in the theoretical framework explaining the concept of globalizations as a form of neocolonialism and the concept of marginalization.

3. Within the discussion section two tourism development case studies will be analyzed: (a) one in the coastal area of Petite Cote in Senegal and (b) the second one in relation to the Antanosy indigenous tribe of Evatra in Madagascar. These two case studies represent how globalization through the 
practice of tourism development have resulted marginalization in economical, ecological, and socio-cultural dimensions.

4. The last section will outline the conclusion regarding the findings within the case studies in relation to the theoretical framework.

\section{Research Findings}

\subsection{Case Studies}

Tourism being a byproduct of globalization has also shown evidence of marginalization. With the purpose of exemplifying this, in the following section two case studies have been identified, through which the marginalization of rural traditional communities has become evident due to the effects of globalization and tourism development. A neocolonialist profitdriven discourse has become also evident in this case exemplifying the main argument of this article.

\section{Case Study \#1: Petite Cote, Senegal}

Reference: Diagne, A. (2004). Tourism development and its impacts in the Senegalese Petite Côte: a geographical case study in centre-periphery relations. Tourism Geographies, 6(4), 472-492.

A study in the coastal tourist destination of Petite Cote in Senegal written by Diagne (2004) has elaborated upon the development of the tourism industry resulting in the marginalization of the local community. The author has studied the case from a neocolonial perspective, building upon the work of Galtung (1980) on neo-colonial penetration and control and relating it to the concept of economy dependency from Hall and Page (1999). From this theoretical framework, he refers to Mathieson and Wall (1982) who establish that: "the development of tourism may be accompanied by a one-way transfer of wealth from the destination area to points of tourist generation. A large proportion of expenditures and profits flow back to foreign investors" (p. 148). This set of concepts are very much in line with the theoretical framework created for this scientific article, since they explain the marginalization process being derived from a neocolonial structure reflected in the tourism industry and how underdeveloped countries are still being exploited by developed Western countries in the contemporary economy.

The author explains how Senegal being a former French colony, and as other former colonies in the world, has recently turned its focus towards the tourism industry as an alternative source for economic growth. By the time the study was written the number of tourist arrivals has increased from 90,000 in 1995 to 350,000 in 1998 (Ndaw 1999), and between 1 and 1.5 million tourists were expected by 2005 (Minister for Tourism and Surface Transportation) (1997). As explained by the author: "Tourism has evolved over the past three decades into the chief economic activity in the country, contributing more foreign currency than traditional primary commodity exports." (p. 473). This shows that the economic growth discourse is predominant within a postcolonial underdeveloped country such as Senegal, and the strong pressure this discourse generate on their inhabitants to find profit oriented activities. As a consequence, the rise of corporate power has also become evident within the tourism sector and the author explains that since the introduction of new legislation in October 1971 and investment regulations in June 1972, Senegal government have established tourism as a key political priority in social and economic development planning. Additionally, the government in 1975 set up a special enterprise, the Societe d'Amenagement de la Petite Cote (SAPCO), whose main function ranges from basic planning to the construction of infrastructure indispensable for tourism to thrive. This has enhanced government and private entrepreneurs to seek more beachfront land for development. This as cited from the author has created "a welter of dependencies that have crystallized here: on imported skilled labor, foreign capital, imported goods, international development and planning (large transnational hotel chains, mainly French-owned) and of course tourists themselves, largely from abroad. In addition, the tourist 'enclaves' tend to 'peripherize' the surrounding traditional villages, turning part of their working force into menial laborers in the developed tourist enclave." (p. 475)

It can be argued that the growth of corporate power in Senegal has proved Goldsmith's argument (1997) about "Development as Colonialism" industrialize underdeveloped countries. Unluckily, this was not solely a philanthropic reasons and 
social integration between French as an ex-colonizer and Senegal. Rather it was spirited by the need to incorporate the Western trading system with the aim of creating a global market for the French-owned company goods and services and at the same time securing a source of cheap labor and raw materials for this global tourism industry.

Furthermore, it is explained that tourism is also apparently attractive for independent indigenous enterprises in the areas of handicrafts and entertainment and also provides a source of income for workers in hotels and labor force in the infrastructure and equipment field. However, the author argues that tourism development at the same time has had a negative impact. We argue that this can be seen as marginalization of the traditional community within the area undermining other traditional forms of development that can be englobed within the environmental, spiritual and socio-cultural spheres as follows:

Regarding environmental issues the author identified environmental deteriorations resulting from a lack of proper liquid and solid waste management as well as new previously inexistent sources of pollution as tourist accommodation proliferates. The traditional management of natural resources has also been shaken because of a shift in the use of land towards leisure activities at the direct expense of agricultural cultivation. This has caused the loss of the necessary resources for the locals to engage in traditional fishing, which was previously the main economic activity and indirect source of subsistence. Regarding the socio-cultural sphere, the author states that international tourism has disintegrated the social structures within the locality. New health problems such as AIDS and the breakdown of social control have arisen. The cultural identity of the inhabitants has also been shaking by the trivialization of their culture: "as indigenous artistic crafts are 'modernized' and commercialized to cater to the needs of the tourist marketplace" (p. 473). Finally, within the spiritual sphere the author argues that tourism has brought a new 'immorality' and thus the violation of traditional Islamic codes of behavior.

As explained by the author: "tourism development in the Petite $\mathrm{C}^{\wedge}$ ote is pressing forward at a swift pace, oriented to maximizing profit and with the evident exclusion of most of the local population." (p. 472). In his own terms, he concludes that such development in inevitably followed by 'misdevelopmental' impacts which directly supports my main argument regarding globalization and tourism development as a cause of economic and social marginalization in traditional communities, which will never create local's economic happiness.

\section{Case Study \#2: Antanosy of Evatra, Madagascar} Reference: Mulligan, P. (1999). The marginalization of indigenous peoples from tribal lands in southeast Madagascar. Journal of International Development, 11(4), 649.

A second study case drawn from the Southeast of Madagascar in the area of the Antanosy indigenous of Evatra written by Mulligan (1999) analyses how international tourism has been leading to the marginalization of the indigenous people in relation to land. Using the conceptual framework of marginalization and international tourism the author explores how select groups within the village have been affected by the development of the region's international tourist trade, specifically by external tour operators. As explained by the author, Madagascar being a former French colony, at the moment of the research was one of the poorest countries in the world. Ironically the country in the late 90's had multiple sources of foreign investment reflected in Trans-National Corporations (TNC) and Non-Governmental Organizations (NGOs). Regarding the tourism industry, it is a prime ecotourism destination offering wildlife reserves, local villages and unique ecosystems. As stated by the author "the endemic nature of much of the region's flora and fauna has prompted some environmental NGO's to promote a speciesoriented 'conservation' discourse founded more on Western sentimentalities than local realities" (p. 651). It can be said that the tourism industry is being strongly influenced by a Western originated discourse regarding conservation, since as the 
author stated, conservation initiatives have arisen to meet the idealized needs Western have defined rather than deep-rooted needs stated by the localities themselves.

This Westernized-driven conservation of ecotourism industry in Madagascar by disregarding localities has arisen what is explained by Hall (2013) about marginalization. Indirectly, disentanglement of traditional communities in the discussion of conservation discourse is an unfavorable condition to cultural and social aspect, which potentially leads to environmental sphere.

To be informed, the coastal Antanosy village of Evatra is characterized as being one of the 18 ethnic groups in Madagascar. Its population at the moment was 1,300 and primarily dependent on fishing and weaving for small scale trading and income generation and rice and manioc being grown for personal consumption. They mainly had an economy relied on self-subsistence apart from the small scale economic transactions. The author explains that regarding land "the Antanosy do not conceptualize land as a homogenous entity. They distinguish differences in land use, varying in spiritual and ancestral significance, the type of landowner and the type of ownership (traditional, legalized, and semi-legalized). A single piece of land, therefore, may be categorized in a multidimensional way, with different actors articulating different versions or the same actor having a multilayered understanding" (p. 562). Even since after the colonial times, the French introduced legalized ownership of land. However, the indigenous people in this area carried on with this traditional conception and use of it without the necessity of acquiring official titles.

With the rise of international tourism and resulting from tour operator activities regarding the use of land, local villagers are undergoing marginalization from their family plots, their communally owned areas and even their own cemetery. The author identified three types of marginalization experienced by them, namely in terms of access to their land, title to their land and decision-making process within their land. This reflects a form of neocolonialism whereby local and traditional livelihoods are being discarded, and in turn the imposition of a norm that doesn't belong to the inhabitant's reality dominates and governs.
This can be seen as an evident form of economic as well as social marginalization. As explained by the author referring to Tully (1994) "Not only are they (the local indigenous) inhibited in this process by their illiteracy and lack of full comprehension of the process involved, but by endorsing the idea that indigenous people should have to claim their traditional land from the State, they are inadvertently perpetuating a form of 'conceptual imperialism" (p.658). The indigenous, in addition to this, also lack the knowledge resources and power to undergo the process necessary to legalize their lands.

As concluded by the author "international tourism is just one of the external dynamics that is affecting the village land issue in the area considering that other global forces, such as the increasing exportation of seafood, the work of international NGOs, and the activities of the world's largest mining corporation area" also highly significant within the context of Madagascar. Therefore, it can be observed how a neocolonial discourse in a globalized world favoring nonlocal profit driven private tour operators and, in a general context as stated before, big profit driven corporations, result in the marginalization of the local traditional Antanosy indigenous of Evatra undermining any other form of development that does not fit into the colonial imperial discourse.

According to the two presented case studies in ex-colony of French (Senegal and Madagascar), today's tourism development has led to an obvious marginalization (environmental, cultural, social, economic and political). The discussion cannot disregard the involvement of ex-colonizer in tourism industry due to the fact that French-owned company and another form of corporate power have driven the direction of tourism development, which is knowingly called as a practice of "neocolonialism" in the modern era. In this regard, there is an interrelation between marginalization and neocolonialism in the development of global tourism industry where local's government make corporate power live under neocolonialism shadow to conduct tourism development in a traditional communities' area. Meanwhile, at the same time the government seems letting local's die by ignoring the practice of marginalization caused by the practice of neocolonialism. A cause and effect relationship implies in neocolonialism and marginalization 
where foreign investment with the domination of neoliberal principles expropriates resources of underdeveloped countries in the name of social integration and philanthropic agenda.

\section{Conclusion}

The idea of development through globalization in tourism has been driven by First World countries. Development in the context of tourism aims to enhance the growth of economic aspects. The presence and implication of neoliberalism and capitalism in Third World countries through transnational group and multinational corporations' establishments have led to the marginalization toward the local community. The consensual view of empowering ex-colonial countries within Western development discourse has failed to create empowered communities. As happened in the case study in Petite Cote, Senegal and Antanosy village of Evatra, Madagascar local communities in rural area have been marginalized, disrupted and destroyed not only within the respect of economic dimensions but also environmental, sociocultural, and ecological dimensions. Natural resources have become a commodity in free a market economy and boundaries have been established between private property owners excluding locals from access to their own resources. Locals do not get positive benefits as much as global institutions receive. In fact, the practice exploitation in the name of competition and free trade directly create a detrimental impact among locals in environment, ecology, and socio-culture, disintegrating the core structure of their traditional livelihoods.

In response to this, globalization continuously happened with the purpose of empowering, modernizing, and enhancing the quality of life in the Third World countries. However, the idea of this forms of development is a charming package of practicing neo-colonialism and modern imperialism in the tourism industry.

\section{References}

Ahmed, W. (2010). Neoliberalism, Corporations, and Power: Enron in India. Annals of Association of American Geographers, 621-639.

Amin, S. (2000). The political economy of the twentieth century. Monthly Review, 52(2), 1.
Bebbington, A. (1999). Capitals and capabilities: a framework for analyzing peasant viability, rural livelihoods and poverty. World development, 27(12), 2021-2044.

Burton, M., Kagan, C., Burns, D., Crespo, I., Evans, R., Knowles, K., et al. (2002). Working with People Who Are Marginalized by The Social System: Challenges for Community Psychological Work. London: Macmillan.

Chambers, R., \& Conway, G. (1992). Sustainable rural livelihoods: practical concepts for the $21 \mathrm{st}$ century. Institute of Development Studies (UK).

Cheng, M. Y., \& Mittelhammer, R. (2017). Globalization and Economic Development: Impact of Social Capital and Institutional Building. American Journal of Economic and Sociology, 859-888.

Chesnais, F. (2003). Globalisation against development: liberalisation, deregulation and privatisation as antithetic to growth. Innovation Systems and Development Strategies for the Third Millennium (pp. 1-17). Rio de Janeiro: GLOBELICS.

Chomsky, N. (2000). Rogue states: The rule of force in world affairs. London: Pluto Press.

Dang, G., \& Pheng, L. (2015). Theories of Economic Development. Infrastructure Investments in Developing Economics, 11-25.

Diagne, A. (2004). Tourism development and its impacts in the Senegalese Petite Côte: a geographical case study in centre-periphery relations. Tourism Geographies, 6(4), 472-492.

Escobar, A. (1997). The making and unmaking of the third world through development. The postdevelopment reader, 85-93.

Galtung, J. (1980) The True Worlds: A Transnational Perspective (New York: Free Press)

Garoupa, N. (2013). Globalization and Deregulation of Legal Service. International Review of Law and Economics, 77-86.

Goldsmith E. and Mander, J. (2014). The case against the global economy: and for a turn towards localization. Routledge.

Hall, C. M. \& Page, S. J. (1999) The Geography of Tourism and Recreation: Environment, Place and Space (London: Routledge).

Hall, C. M., Harrison, D., Weaver, D., \& Wall, G. (2013). Vanishing peripheries: does tourism consume places?. Tourism Recreation Research, 38(1), 71-92.

Hanson, M., \& Hentz, J. J. (1999). Neo-Colonialism and Neo-Liberalism in South Africa and Zambia. The Journal of Public and International Affairs , 479-502.

Kelly, L. (2009). Neoliberalism in Latin America. Retrieved April 18, 2017, from Citizen's Press: 
http://cpress.org/editorials/old/neoliberalism-inlatin-america

Korten, D. C. (1998). When corporations rule the world. European Business Review, 98(1).

Levy, B. (2012). The Role of "Globalization" in Economic Development. SSRN Electronic Journal , 1-7.

Kotz, D. M. (2002). Globalization and Neoliberalism. Rethinking Marxism, 64-79.

Leonard P. 1984. Personality and Ideology: Towards a materialist understanding of the individual. Blackwell: Oxford.

Mathieson, A. \& Wall. G. (1982) Tourism:Economic,P hysicalandSocialImpacts (Harlow: Longman).

McChesney (1998). Introduction for: Chomsky, Noam. Profit over people: Neoliberalism and global order. Seven Stories Press, 1999.

McLaren, D. (2003). Rethinking tourism and ecotravel. Kumarian Press.

Monbiot, G. (2016, April 15). Neoliberalism - The Ideology at The Root of All Our Problems. Retrieved April 10, 2017, from The Guardian: https://www.theguardian.com/books/2016/ apr/15/neoliberalism-ideology-problem-georgemonbiot

Mukherji, R. (2004). Globalization and Deregulation: Ideas, Interests, and Institutional Change in India. Oxford: Oxford Scholarship.

Mulligan, P. (1999). The marginalization of indigenous peoples from tribal lands in southeast Madagascar. Journal of International Development, 11(4), 649.

Murshed, S. M. (2000). Globalization, Marginalization, and Development. Helsinki: World Intitute for Development Economics Research.

Ndaw, M. (1999) L'objectif d'un million de touristes renvoy' e ' a l'horizon 2005, Le Soleil. Availableatwww.metissacana.sn/Rubriques $\% 20$ Infos/Economies/ econo2.html (accessed 21 September 1999).

Nkrumah, K. (1965). Neo-Colonialism, The Last Stage of Imperialism. London: Thomas Nelson \& Sons, Ltd.

Norberg-Hodge, H. (2011). The Economics of Happiness. Dir. Gorelick S., Norberg-Hodge, H. and Page, J.

Pandit, S. (2012). Marginalization of the Tharu Ethnic Group in Tourism Development in Nepal. Turizam , 40-49.

Patnaik P, 2000. The Political Economy of Imperialism: Critical Appraisals. Boston Way, Maryland: Rowman \& Littlefield Publishers, Inc., 169-180

Petras, J., \& Veltmeyer, H. (2001). Are Latin American peasant movements still a force for change? Some new paradigms revisited. The Journal of Peasant Studies, 28(2), 83-118.
Pilger, J. (2002). The new rulers of the world. London: Verso.

Potter, L. (2000). Rural livelihoods and the environment at a time of uncertainty: the situation outside Java.

Quah, D. T. (1996). Empirics for economic growth and convergence. European economic review, 40(6), 1353-1375.

Scott, B. R. (2006). The Political Economy of Capitalism. New York: Harvard Business School Working Paper.

Smith, A. (1976). An Inquiry into The Nature and Causes of The Wealth of Nations. Oxford: Clarendon Press.

State, A. E. (2010). Marginalized Livelihoods Under Neo-Liberal Development Policies in Uganda. International Journal of Sociology and Anthropology, 224-235.

Tully, J. (1994). Aboriginal property and western theory: Recovering a middle ground. Social Philosophy and Policy, 11(02), 153-180.

UNDP. (2017). Human Development Report. New York: UNDP.

Weyland, K. G. (2004). Neoliberalism and Democracy in Latin America: A Mixed Record. Latin Maerican Politics \& Society, 135-157.

Zhao, W., \& Li, X. (2006). Globalization of tourism and third world tourism development. Chinese Geographical Science, 16(3), 203-210. 